\title{
AKUNTABILITAS ANGGARAN PENDAPATAN DAN BELANJA DESA GARON KECAMATAN KAWEDANAN KABUPATEN MAGETAN
}

\author{
Pipit Juliana1 \\ Pendidikan Akuntansi FKIP \\ Universitas PGRI Madiun \\ Pipitjuliana65@yahoo.co.id
}

\author{
Purweni Widhianningrum ${ }^{2}$ \\ Pendidikan Akuntansi FKIP \\ Universitas PGRI Madiun \\ weni.widhi@gmail.com
}

\begin{abstract}
ABSTRAK
Penelitian ini bertujuan untuk mengetahui proses penyusunan dan akuntabilitas Anggaran Pendapatan dan Belanja Desa Garon Tahun 2016. Pendekatan penelitian ini menggunakan kualitatif deskriptif. Hasil penelitian menunjukkan bahwa akuntabilitas hukum dan kejujuran Desa Garon telah berpedoman pada Undang-Undang RI No.06 Tahun 2014, Peraturan Menteri dalam Negeri No.83, 113 dan 114, Peraturan Pemerintah No.60 Tahun 2014, dan Peraturan Bupati Magetan No.12 Tahun 2015. Akuntabilitas manajerial pemerintah Desa Garon telah melibatkan masyarakat, seluruh perangkat desa, tim pelaksana, BPD, LPM dan Karang Taruna. Akuntabilitas program Desa Garon dengan mengikutsertakan masyarakat dalam menyusun program desa. Akuntabilitas finansial pemerintah Desa Garon terhadap Anggaran Pendapatan dan Belanja Desa Garon dapat dikatakan cukup ekonomis, tidak efesien, namun memberikan kontribusi pembangunan yang dapat dikatakan cukup efektif bagi perekonomian masyarakat Desa Garon.
\end{abstract}

Kata Kunci : Akuntabilitas hukum; akuntabilitas manajerial; akuntabilitas program desa; akuntabilitas APBDesa

\begin{abstract}
This study aims to determine the process of preparing and accountability of Garon Village Revenue and Expenditure Year 2016. This research approach uses descriptive qualitative. The results show that the legal accountability and honesty of Garon Village has been guided by RI Law No.06 of 2014, Regulation of the Minister of Home Affairs No.83, 113 and 114, Government Regulation No.60 Year 2014, and Regulation of Magetan Regent No.12 Year 2015. Managerial accountability Garon Village government has involved the community, all village units, implementing teams, BPD, LPM and Karang Taruna. Accountability Garon Village program by involving the community in preparing the village program. The financial accountability of the Garon Village government to the Garon Village Revenue and Expenditure Budget can be said to be quite economical, inefficient, but contributes to the development which can be said to be quite effective for the economy of Garon Village society.
\end{abstract}

Keywords: Legal accountability; managerial accountability; accountability of village programs; accountability of APBDesa

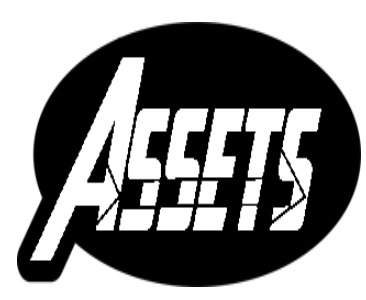

ASSETS

Jurnal Akuntansi dan Pendidikan Vol. 6 No. 2

Hlmn. 169-183

Madiun, Oktober 2017 p-ISSN: 2302-6251 e-ISSN: 2477-4995

Artikel masuk: 16 Oktober 2017 Tanggal diterima: 28 Oktober 2017 


\section{PENDAHULUAN}

Penyelenggaraan pemerintah desa tidak terpisahkan dari penyelenggaraan otonomi daerah, dan pemerintahan desa merupakan unit terdepan (ujung tombak) dalam pelayanan kepada masyarakat sehingga menjadi tonggak yang strategis untuk keberhasilan semua program yang telah direncanakan. Sebagai unit terdepan maka pemerintah desa harus mampu memberikan pelayanan yang terbaik kepada masyarakat. Sebagai organisasi yang paling dekat dengan masyarakat, pemerintah memberikan dana yang cukup besar kepada pemerintah desa guna meningkatkan pembangunan dan pemberdayaan masyarakat. Dana tersebut kemudian dicatat dan dikelola dalam Anggaran Pendapatan dan Belanja Desa (Widjaja dalam Suharto, 2016: 6). Peningkatan volume transaksi yang semakin besar dan semakin kompleks harus diikuti dengan peningkatan kemampuan pengelolaan keuangan pemerintah (Sugijanto dalam Hariyani dan Sudrajat, 2016: 114).

Penyusunan Anggaran Pendapatan dan Belanja Desa harus memenuhi beberapa prinsip yaitu kepatuhan hukum, tertib penyelenggaraan pemerintahan, tertib kepentingan umum, keterbukaan, proporsionalitas, profesionalitas, akuntabilitas, efektivitas, kearifan lokal, keberagaman dan partisipatif. Dari beberapa prinsip disebutkan salah satunya akuntabilitas, akuntabilitas yang dimaksud adalah prinsip yang menentukan bahwa setiap kegiatan dan hasil akhir kegiatan dipertanggungjawabkan kepada masyarakat desa sesuai perundang-undangan (Undang-undang Republik Indonesia No.06 Tahun 2014). Dalam konteks organisasi publik, akuntabilitas publik berarti pemberian informasi dan disclosure terhadap aktivitas dan kinerja finansial pemerintah kepada pihak-pihak yang berkepentingan. Pemerintah pusat maupun daerah harus bisa menjadi subyek pemberi informasi dalam rangka pemenuhan hak-hak publik (Mardiasmo, 2009: 21). Mulgan (dalam Mahmudi, 2015: 09) menjelaskan bahwa akuntabilitas publik diperlukan guna mengantisipasi dan meminimalkan timbulnya pemerintahan yang menyimpang. Penanggungjawab laporan keuangan desa adalah kepala desa.

Beberapa penelitian tedahulu yang berhasil membuktikan bahwa akuntabilitas Anggaran Pendapatan dan Belanja Desa sangat diperlukan guna mempertanggungjawabkan dana yang telah diberikan pemerintah daerah terdapat dalam penelitian Kurniawan, Made dan Yogivaria (2014) yang bertujuan untuk mendeskripsikan akuntabilitas pengelolaan Alokasi Dana Desa, berhasil membuktikan bahwa sebagaian besar dari Alokasi Dana Desa digunakan untuk pemberdayaan masyarakat, biaya operasional pemerintah desa dan untuk Badan Permusyawaratan Desa. Pengawasan dalam pelaksanaan Alokasi Dana Desa terjadi dari 3 jenis pengawasan. Pertama, pengawasan fungsional, seharusnya dilakukan setiap bulan (laporan berkala) dan setiap akhir tahun (Surat Pertanggungjawaban). Kedua, pengawasan yang dilakukan atasan melalui struktur organisasi pemerintah desa. Ketiga, pengawasan langsung oleh masyarakat. Pertanggungjawaban Alokasi Dana Desa dilakukan dengan pertanggungjawaban secara administratif dan pertanggungjawaban secara langsung kepada masyarakat.

Penelitian Lestari, Atmadja dan Adiputra (2014) yang bertujuan untuk mengetahui proses, keterlibatan aparat desa, serta memahami dan memaknai akuntabilitas pengelolaan keuangan di Desa Pakraman Kubutambahan, berhasil membuktikan bahwa proses pengelolaan dan pertanggungjawaban keuangan tidak melibatkan seluruh Krama Desa melainkan hanya malalui perwakilan. Akuntabilitas pengelolaan keuangan berlangsung secara konsisten setiap bulan dengan menggunakan sistem akuntansi sederhana. Dengan adanya modal sosial khususnya 
kepercayaan, menyadari bahwa akuntansi merupakan instrument akuntabilitas dan transparansi dalam pengelolaankeuangan di Desa Pakraman.

Penelitian lain dilakukan oleh Faridah dan Suryono (2015) yang bertujuan untuk mengetahui seberapa jauh penerapan prinsip-prinsip transparansi dan akuntabilitas kepala desa dalam pengelolaan APBDes di Desa Sidogedungbatu Kecamatan Sangkapura Kabupaten Gresik, berhasil membuktikan bahwa transparansi dan akuntabilitas sudah berjalan dengan baik. Dilihat dari program Alokasi Dana Desa yang berlandaskan hukum. Dalam perencanaan Alokasi Dana Desa telah melibatkan masyarakat sesuai dengan hasil wawancara. Pelaporan Alokasi Dana Desa dibuktikan dengan pertanggungjawaban pelaksanaan program Alokasi Dana Desa dan Anggaran Pendapatan dan Belanja Desa kepada pemerintah tingkat atasnya secara periodik. Meskipun begitu musyawarah rencana pembangunan desa dirasa kurang baik karena tim pelaksana tidak mencantukan anggaran yang dibuat untuk membangun desa dalam papan informasi.

Penelitian Riyanto (2015) yang bertujuan untuk mendeskripsikan akuntabilitas finansial dan identifikasi faktor pendukung maupun penghambat yang mempengaruhi akuntabilitas finansial dalam pengelolaan ADD di Kantor Desa Perangkat Selatan, berhasil membuktikan bahwa pengelolaan ADD dapat dipertanggungjawabkan di depan pihak pemerintah desa, namun belum dapat dipertanggungjawabkan kepada seluruh masyarakat desa. Hal ini dikarenakan masih adanya aturan-aturan baru yang muncul di BPD dan ketua RT, faktor cuaca yang tidak mendukung sehingga kegiatan menyuplai bahan bangunan terlambat, laporan desa masih belum memaksimalkan pemanfaatan waktu dalam penyusunan laporan dan penyelasaiaannya laporan pertanggungjawaban. Sedangkan faktor pendukungnya adalah masih tingginya tingkat partisipasi masyarakat yang tinggi dalam kegiatan pembangunan.

Penelitian Hanifah dan Praptoyo (2015) yang bertujuan untuk mengetahui penerapan akuntansi dan manajemen keuangan yang ada di Desa Kepatihan Kecamatan Menganti Kabupaten Gresik, berhasil membuktikan bahwa proses pencatatan akuntansi telah dilaksanakan namun belum sesuai dengan UndangUndang No.06 Tahun 2014 Tentang Desa. Hal tersebut disebabkan pada proses pencatatan akuntansi, setiap transaksi yang dilakukan hanya dicatat dalam kedalam buku kas harian dan belum di susun ke dalam buku kas umum. Manajemen keuangan sudah menunjukkan pelaksanaan yang akuntabel dan transparan yang dapat dilihat dari pelaporan pertanggungjawaban.

Penelitian Sa'adah (2015) yang bertujuan untuk mengetahui akuntabilitas dan transparansi anggaran melalui e-government (studi tentang penganggaran dipemerintahan daerah Kabupaten Blitar), berhasil membuktikan bahwa pemerintah desa telah mampu menyelenggarakan informasi penyelenggaraan pemerintah secara terbuka, cepat dan tepat kepada masyarakat melalui website-website yang telah dimiliki pemerintah desa. Selain itu, e-government tentang pelaksanaan akuntabilitas anggaran memberikan ruang bagi masyarakat untuk terlibat dalam proses pembangunan dan pemerintahan, sebab masyarakat dapat mengevaluasi kegiatan dan kebijakan anggaran yang dipilih oleh pemerintah. Meskipun begitu pelaksanaan akuntabilitas penganggaran melalui penerapan e-government pada pemerintah Kabupaten Blitar masik kurang maksimal, sebab masyarakat masih belum bisa malihat dan mengakses beberapa dokumen pada saat pembahasan APBD.

Penelitian Setiawan, Habodin dan Wilujeng (2017) berhasil membuktikan bahwa akuntabilitas dalam pengelolaan ADD sudah sesuai dengan prosedur yang berlaku serta dapat terwujud karena adanya pengawasan internal maupun eksternal. Pengawasan secara internal ataupun eksternal dapat memunculkan kesadaran bahwa 
program yang didanai dari ADD harus dipertanggungjawabkan dengan sebaikbaiknya.

Penelitian Arifiyanto dan Kurrohman (2014) yang bertujuan untuk mengetahui penerapan sistem akuntabilitas Alokasi Dana Desa (ADD) di Kecamatan Umbulsari Kabupaten Jember, menunjukkan bahwa perencanaan program Alokasi Dana Desa di 10 desa se Kecamatan Umbulsari telah melaksanakan konsep pembangunan partisipasif dibuktikan melalui Musyawarah Perencanaan Pembangunan Desa (MUSREMBANGDES). Penerapan prinsip akuntabilitas pada tahap pelaksanaan sebatas pertanggungjawaban fisik, sedangkan dari sisi administrasi telah dilaksanakan sesuai ketentuan yang ditetapkan oleh pemerintah kabupaten. Pertanggungjawaban kepada masyarakat berupa fisik sedangkan kepada pemerintah diatasnya berupa bentuk laporan.

Berdasarkan hasil penelitian di atas, maka akuntabilitas sebagai alat pertanggungjawaban terhadap dana yang telah diberikan pemerintah daerah. Seperti halnya Desa Garon yang memperoleh Alokasi Dana Desa dari pemerintah daerah sejak tahun 2015, maka aparat Desa Garon diharapkan mampu mempertanggungjawabkan dana tersebut. Desa Garon merupakan sebuah desa yang terletak di Kecamatan Kawedanan Kabupaten Magetan Provinsi Jawa Timur. Dari keseluruhan jumlah penduduk Desa Garon sebanyak 75\% bermatapencaharian sebagai petani. Hasil pertanian masyarakat Desa Garon sebagian besar adalah padi, tebu, kacang tanah, kedelai dan sayur-sayuran. Sehingga kiranya anggaran yang diberikan pemerintah daerah Kabupaten Magetan diharapkan untuk pembangunan dalam bidang pertanian. Sehingga pembangunan tersebut mampu meningkatkan hasil pertanian dan kesejahteraan masyarakat turut meningkat. Namum pada kenyataannya, dalam penyusunan Anggaran Pendapatan dan Belanja Desa Garon, aparat desa masih mengalami kesulitan, hal tersebut dikarenakan Undang-undang Republik Indonesia No.06 Tahun 2014 baru diterapkan pada tahun 2015, sehingga aparat Desa Garon masih merasa perlu bimbingan dari pemerintah kabupaten dalam menyusun Anggaran Pendapatan dan Belanja Desa, sehingga penyusunan anggaran sesuai perundang-undangan yang berlaku dan dapat dipertanggungjawabkan.

Berdasarkan paparan di atas maka tujuan dari penelitian ini pertama, adalah untuk mengetahui proses penyusunan Anggaran Pendapatan dan Belanja Desa Garon tahun 2016. Kedua, untuk mengetahui akuntabilitas yang diterapkan dalam penyusunan Anggaran Pendapatan dan Belanja Desa Garon tahun 2016.

\section{METODE PENELITIAN}

Jenis penelitian yang digunakan dalam penelitian ini adalah metode kualitatif dengan pendekatan deskriptif. Metode kualitatif menurut Sugiyono (2016 : 13) adalah "metode penelitian yang berlandaskan pada kondisi postpositivisme, digunakan untuk meneliti pada kondisi obyek alamiah, dimana peneliti sebagai instrument kunci, tehnik pengumpulan data dilakukan secara triangulasi, analisis data bersifat induktif atau kualitatif, dan hasil penelitian kualitatif lebih menekankan makna dari pada generalisasi".

Teknik pengumpulan data dalam penelitian ini meliputi wawancara dan dokumentasi. Peneliti menggunakan metode wawancara tidak terstruktur. Pedoman wawancara yang digunakan hanya berupa garis-garis besar permasalahan yang akan ditanyakan. Wawancara dilakukan kepada Kepala Desa Garon, Sekretaris, Bendahara, Anggota Badan Permusyawaratan Desa, dan ketua RT sebagai perwakilan masyarakat Desa Garon. Dokumentasi yang dimaksudkan dalam penelitian ini adalah untuk 


\section{ASSETS}

memperoleh data dengan cara mengumpulkan berbagai dokumen yang terkait dengan Anggaran Pendapatan dan Belanja Desa Garon.

Prosedur penelitian ini mengacu pada pendapat Sugiyono (2016: 247-249). Dimana kegiatan utama saat analisis data adalah tahap analisis sebelum dilapangan dan tahap analisis dilapangan. Berikut gambar prosedur penelitian ini:

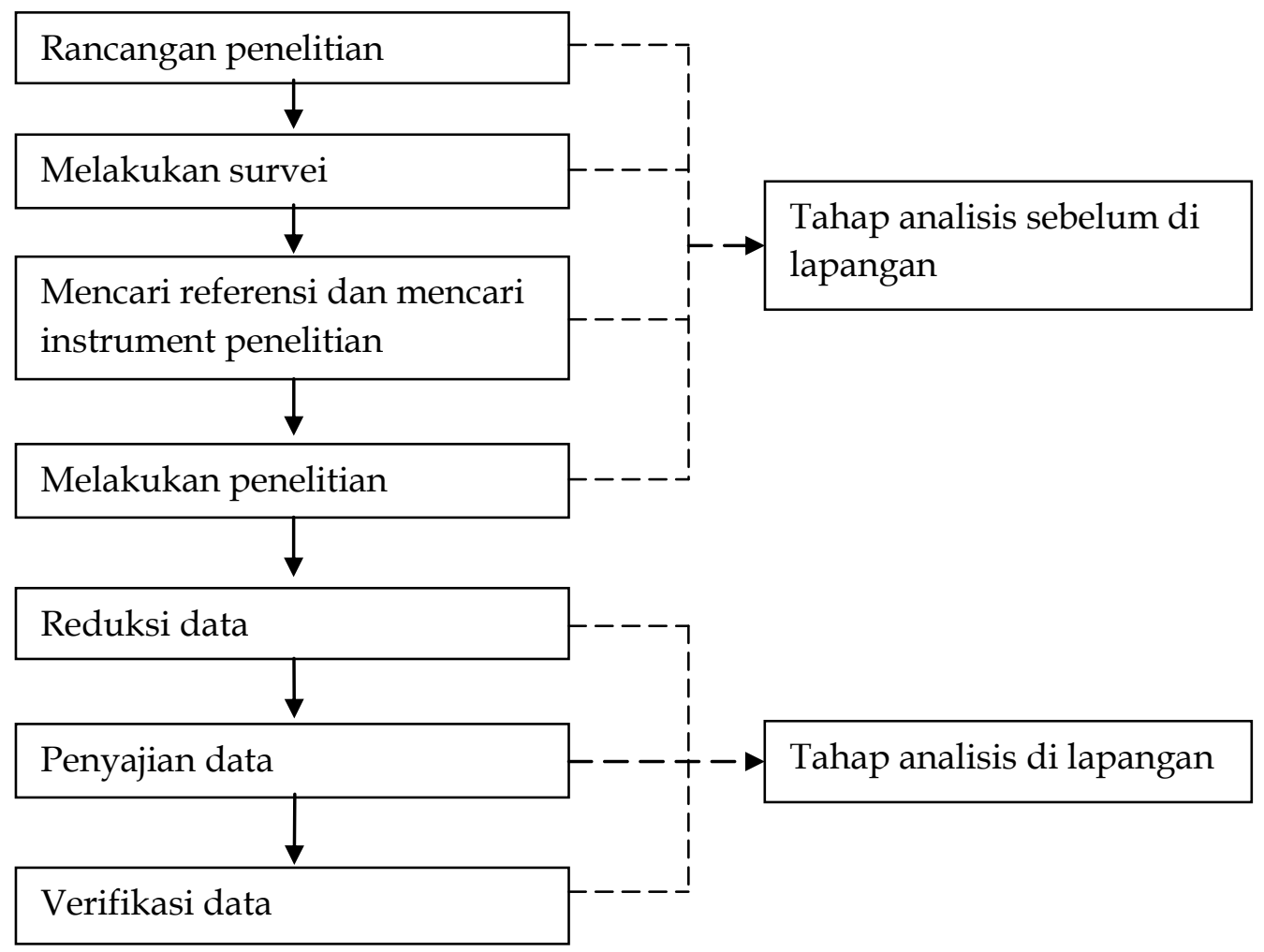

Gambar 1. Prosedur Penelitian

Dalam penelitian ini analisis dilakukan terhadap dimensi-dimensi akuntabilitas. Terdapat lima dimensi yang akan dianalisis dalam penelitian ini, yaitu seperti teori yang dikemukakan Elwood (dalam Mahmudi, 2015) :

a. Akuntabilitas Hukum dan Kejujuran

Akuntabilitas hukum dan kejujuran berarti kepatuhan terhadap hukum dan peraturan lain yang telah disayaratkan dalam menjalankan organisasi (Elwood dalam Mahmudi, 2015: 10).

b. Akuntabilitas Manajerial

Akuntabilitas manajerial berkaitan dengan akuntabilitas proses yang berarti bahwa setiap proses organisasi harus dipertanggungjawabkan (Elwood dalam Mahmudi, 2015: 10).

c. Akuntabilitas Program

Akuntabilitas program berarti tercapainya program-program organisasi yang bermutu dan mendukung visi, misi dan tujuan organisasi (Elwood dalam Mahmudi, 2015: 11).

d. Akuntabilitas Kebijakan

Akuntabilitas kebijakan merupakan pertanggungjawaban lembaga publik terhadap kebijakan yang telah diambil (Elwood dalam Mahmudi, 2015: 11).

e. Akuntabilitas Finansial 
Akuntabilitas finansial berarti pertanggungjawaban lembaga publik untuk menggunakan uang publik secara ekonomis, efektif dan efisien (Elwood dalam Mahmudi, 2015: 11).

\section{HASIL PENELITIAN DAN PEMBAHASAN Hasil Penelitian}

1. Akuntabilitas Hukum dan Kejujuran

Penyusunan Anggaran Pendapatan dan Belanja Desa Garon telah berlandaskan hukum antara lain Undang-undang Republik Indonesia No.06 Tahun 2014 Tentang Desa, Peraturan Pemerintah No.43 Tahun 2014 Tentang Peraturan Pelaksanaan Undang-undang No.06 Tahun 2014, Peraturan Pemerintah No.60 Tahun 2014 Tentang Dana yang bersumber dari Anggaran Pendapatan dan Belanja Desa, Peraturan Mentri dalam Negeri No.113 dan No.114 Tahun 2014 Tentang Pedoman Pengelolaan Keuangan Desa, Peraturan Menteri dalam Negeri No.85 Tahun 2015, Peraturan Daerah Kabupaten Magetan No.10 Tahun 2014 Tentang Anggaran Pendapatan dan Belanja Daerah Tanggal 17 Desember 2014.

2. Akuntabilitas Manajerial

Proses perencanaan Anggaran Pendapatan dan Belanja Desa (APBDesa) dimulai dari Sekretaris Desa menyusun Rencana Pembangunan Jangka Menengah Desa (RPJMDesa) Garon sesuai dengan Rencana Pembangunan Jangka Menengah (RPJM) Kabupaten Magetan, tujuannya agar program yang disusun tidak beda jauh dengan program pemerintah kabupaten. Rencana Pembangunan Jangka Menengah Desa (RPJMDesa) pemerintah Desa Garon digunakan untuk jangka waktu 6 tahun. Setelah itu sekretaris menyusun Rencana Kerja Pembangunan Desa (RKPDesa) yang mengacu pada Rencana Pembangunan Jangka Menengah Desa (RPJMDesa). Rencana Kerja Pemerintah (RKP) dari sekretaris kemudian diusulkan kepada Badan Permusyawaratan Desa (BPD) melalui Kepala Desa Garon, setelah Badan Permusyawaratan Desa menyetujui maka Rencana Kerja Pemerintah (RKP) dijadikan peraturan desa. Selanjutnya sekretaris menyusun Anggaran Pendapatan dan Belanja Desa Garon sesuai dengan Rencana Kerja Pemerintah. Rancangan Anggaran Pendapatan dan Belanja Desa yang disusun sekretaris diserahkan kepada Kepala Desa Garon untuk diajukan ke Badan Permusyawaran Desa (BPD) dan di musyawarahkan bersama seluruh perangkat, Lembaga Pemberdayaan Masyarakat dan karang taruna. Apabila telah mencapai kesepakatan maka hasil musyawarah di laporkan ke Bupati Magetan. Setelah bupati menyetujui maka Desa Garon memperoleh anggaran untuk melaksanakan kegiatan yang tercantum dalam Anggaran Pendapatan dan Belanja Desa Garon.

Pelaksanaan Anggaran Pendapatan dan Belanja Desa Garon dimulai dengan tim pelaksana mengajukan Surat Permintaan Pembayaran (SPP) yang diverifikasi oleh Sekretaris Desa Garon, kemudian diserahkan kepada kepala desa. Apabila Kepala Desa Garon menyetujui maka bendahara dapat mencairkan dana. Sebelum melakukan pencairan dana, bendahara dibantu sekretaris Desa Garon menyusun surat pencairan dana ke bank BRI dengan tanda tangan Kepala Desa Garon. Dana diserahkan kepada ketua tim pelaksana untuk belanja bahan material dan jasa. Ketua tim pelaksana sebagai penanggungjawab berkewajiban membuat Surat Pertanggungjawaban (SPJ) sebagai bentuk pertanggungjawaban.

Proses pertanggungjawaban pemerintah Desa Garon yaitu, tim pelaksana menyerahkan semua bukti pengeluaran yang digunakan untuk melaksanakan program kepada bendahara desa. Selanjutnya bendahara melakukan pengecekan antara anggaran yang telah diberikan dengan bukti pengeluaran. Apabila telah sesuai 
maka bendahara memberikan bukti pengeluaran kepada sekretaris desa untuk disusun ke dalam laporan pertanggungjawaban. Laporan pertanggungjawaban diajukan kepada kepala desa untuk dilaporkan kepada bupati sebagai bentuk pertanggungjawaban Anggaran Pendapatan dan Belanja Desa Garon. Berdasarkan data yang diperoleh dan kesimpulan wawancara laporan pertanggungjawaban Desa Garon hanya dilampiri laporan pertanggungjawaban pelaksanaan Anggaran Pendapatan dan Belanja Desa (APBDesa) dan laporan kekayaan milik desa, sedangkan laporan program pemerintah dan pemerintah daerah yang masuk desa tidak disusun karena selama tahun 2016 tidak ada program pemerintah yang masuk desa. Pertanggungjawaban kepada masyarakat belum dilaksanakan oleh pemerintah Desa Garon, hal tersebut diketahui dari hasil observasi peneliti. Dimana pemerintah Desa Garon belum membuat papan informasi di desa mengenai Anggaran Pendapatan dan Belanja Desa (APBDesa).

3. Akuntabilitas Program

Selama tahun 2016 Dana Desa Garon lebih banyak digunakan untuk pembangunan. Total dana yang diterima Desa Garon sebesar Rp 1.142.843.787. Tabel 1 menunjukkan program pembangunan desa merupakan prioritas utama, diikuti penyelenggaraan pemerintahan, pembinaan kemasyarakatan, dan pemberdayaan masyarakat. Total anggaran yang digunakan untuk pelaksanaan program senilai Rp 1.098.849.787, nilai ini memiliki selisih lebih Rp 43.994.000 dari dana yang diterima pemerintah Desa Garon. Hal tersebut dikarenakan terdapat program yang tidak dapat terlaksana atau dalam pelaksanaan program terdapat selisih lebih antara target anggaran dengan realisasi anggaran, sehingga sisa lebih anggaran tersebut diakui sebagai Sisa Lebih Perhitungan Anggaran (SILPA). Sisa Lebih Perhitungan Anggaran (SILPA) Desa Garon digunakan untuk mendanai pelaksanaaan program tahun berikutnya. Pengelolaan Sisa Lebih Perhitungan Anggaran di Desa Garon ini telah sesuai dengan Undang-undang RI No.06 Tahun 2014.

Tabel 1. Skala Prioritas Program Desa Garon Tahun 2016

\begin{tabular}{clcr}
\hline No. & \multicolumn{1}{c}{ Program } & \multicolumn{2}{c}{ Total Anggaran } \\
\hline 1. & Pelaksanaan pembangunan Desa Garon & $\mathrm{Rp}$ & 553.322 .000 \\
\hline 2. & Penyelengaraan pemerintahan Desa Garon & $\mathrm{Rp}$ & 359.627 .790 \\
\hline 3. & Bidang pembinaan kemasyarakatan & $\mathrm{Rp}$ & 46.715 .000 \\
\hline 4. & Bidang pemberdayaan masyarakat & $\mathrm{Rp}$ & 34.700 .000 \\
\hline Total & & $\mathrm{Rp}$ & 1.098 .849 .787 \\
\hline
\end{tabular}

Selanjutnya berdasarkan Tabel 1 mengenai skala prioritas program Desa Garon, alokasi dana desa lebih banyak digunakan untuk pelaksanaan pembangunan desa. Prioritas pembangunan desa melalui proses yang cukup panjang yaitu pembangunan yang dilakukan pemerintah Desa Garon atas dasar aspirasi dari masyarakat yang ditampung dalam musyawarah desa. Hasil musyawarah Desa Garon bersama seluruh perangkat desa, Badan Permusyawaratan Desa, Lembaga Pemberdayaan Masyarakat dan karang taruna menunjukkan kurangnya sarana dan prasarana.Sehingga anggota musyawarah menyepakati untuk melakukan pembangunan dibidang sarana dan prasarana.

Keberhasilan pembangunan sarana prasarana dapat dilihat melalui nilai keberhasilan program. Berdasarkan Tabel 2, keberhasilan program yang dilakukan pemerintah Desa Garon telah menunjukkan nilai yang berhasil. Sedangkan beberapa pembangunan memiliki nilai sangat berhasil. Hal tersebut dikarenakan realisasi pembangunan jauh lebih baik dari yang ditargetkan. Sehingga hasil pembangunan yang dilakukan sangat memuaskan. 
JULIANA, P., \& WIDHIANNINGRUM, P. AKUNTABILITAS ANGGARAN PENDAPATAN....

Tabel 2. Nilai Keberhasilan Program

\begin{tabular}{llrl}
\hline No & \multicolumn{1}{c}{ Program } & $\begin{array}{c}\text { Nilai } \\
\text { Keberhasilan }\end{array}$ & Keberhasilan \\
\hline 1. & Pembangunan pagar Balai Desa Garon & $99,54 \%$ & Berhasil \\
\hline 2. & Pembangunan saluran irigasi blok gaprang & $100,34 \%$ & Sangat berhasil \\
\hline 3. & Pembangunan saluran irigasi blok piket & $100,41 \%$ & Sangat berhasil \\
\hline 4. & Penyemiran jalan RT 1, 2, 3, 4, 6 RW 02 & $97,87 \%$ & Berhasil \\
\hline 5. & Penyemiran jalan RT 5 dan 7 RW 2 & $99,56 \%$ & Berhasil \\
\hline 6. & Pembangunan Talud RT 05 RW 01 & $100 \%$ & Sangat berhasil \\
\hline
\end{tabular}

4. Akuntabilitas Kebijakan

Pengambilan kebijakan Desa Garon dilakukan melalui musyawara desa. Dimana musyawarah dilakukan bersama seluruh perangkat Desa Garon, Badan Permusyawaratan Desa, Lembaga Pemberdayaan Masyarakat dan karang taruna untuk menampung aspirasi masyarakat. Aspirasi dari masyarakat Desa Garon diselaraskan dengan arah dan kebijakan pemerintah Kabupaten Magetan dan disesuaikan dengan visi misi Desa Garon. Selanjutnya pemerintah Desa Garon melakukan pengkajian keadaan desa, yaitu pembangunan yang dilakukan adalah pembangunan yang paling mendesak. Kebijakan yang diambil oleh pemerintah Desa Garon didukung dengan daftar usulan Rencana Kerja Pemerintah Desa (RKPDesa), daftar berita acara, dan rancangan Rencana Pembangunan Jangka Menengah Desa (RPJMDesa). Namun dalam pengambilan kebijakan Desa Garon tidak disertai daftar sumber daya alam dan daftar sumber daya manusia. Realita di Desa Garon menunjukkan banyak area persawahan dan adanya sumber daya manusia. Sehingga mendukung kebijakan yang diambil oleh pemerintah Desa Garon.

Berdasarkan proses pengambilan kebijakan diatas selama tahun 2016 pemerintah Desa Garon melakukan beberapa pembangunan antara lain pembangunan pagar balai Desa Garon, pembangunan saluran irigasi (area persawahan), pembangunan talud irigasi, dan penyemiran jalan. Pembangunan pagar Balai Desa Garon ditujukan agar warga sekitar tidak terganggu dengan aktivitas yang dilakukan warga di Balai Desa Garon. Pembangunan saluran irigasi blok gaprang dan blok piket dilakukan untuk memudahkan petani melakukan pengairan, hal tersebut dikarenakan blok gaprang dan blok piket merupakan area persawahan. Penyemiran jalan RW 02 tujuannya untuk membantu aktivitas masyarakat yang mayoritasnya sebagai petani untuk mendistribusikan hasil pertanian keluar desa. Hal ini dikarenakan jalan RW 02 merupakan akses utama masyarakat yang menghubungkan Dukuh Sambiroto dengan Desa Garon. Pembangunan talud irigasi dilakukan agar aliran air tidak menggerus badan jalan.

\section{Akuntabilitas Finansial}

Akuntabilitas finansial berarti pertanggungjawaban lembaga publik untuk menggunakan uang publik secara ekonomis, efektif dan efisien. Tingkat ekonomi digunakan untuk mengetahui input. Sumber daya di bawah anggaran menunjukkan penghematan, sedangkan di atas anggaran menunjukkan pemborosan. Efisiensi digunakan untuk mengukur seberapa baik organisasi memanfaatkan sumber daya yang dimiliki. Efektifitas digunakan untuk mengukur dampak dari pembangunan yang dilakukan (Mahmudi, 2015: 11).

Tabel 3 menunjukkan nilai pembangunan saluran irigasi blok gaprang, saluran irigasi blok piket, penyemiran jalan RT 05 dan 07, dan pembangunan talud irigasi masing-masing memiliki nilai ekonomi $100 \%$. Hal tersebut mengindikasikan bahwa penggunaan anggaran Anggaran Pendapatan dan Belanja Desa Garon untuk 
membiayai program pembangunan cukup ekonomi. Penyemiran jalan RT 01, 02, 03, 04 dan 06 memiliki nilai 77,88\% yang berarti kurang ekonomi. Target pembangunan yang diinginkan kurang sesuai dengan realisasi. Berdasarkan paparan data tersebut dapat disimpulkan bahwa secara keseluruhan nilai ekonomi telah sesaui dengan yang ditargetkan.

Tabel 3. Nilai Kinerja Ekonomi Pemerintah Desa Garon

\begin{tabular}{llrl}
\hline No & \multicolumn{1}{c}{ Program } & \multicolumn{1}{c}{ Nilai } & \multicolumn{1}{c}{ Keterangan } \\
\hline 1. & Pembangunan pagar Balai Desa Garon & $100 \%$ & Cukup Ekonomis \\
\hline 2. & Pembangunan saluran irigasi blok gaprang & $100 \%$ & Cukup Ekonomis \\
\hline 3. & Pembangunan saluran irigasi blok piket & $100 \%$ & Cukup Ekonomis \\
\hline 4. & Penyemiran jalan RT 1, 2, 3, 4, 5 RW 02 & $77,88 \%$ & Kurang Ekonomis \\
\hline 5. & Penyemiran jalan RT 5, 6 dan 7 RW 2 & $100 \%$ & Ekonomis \\
\hline 6. & Pembangunan Talud & $100 \%$ & Cukup Ekonomis \\
\hline
\end{tabular}

Selanjutnya nilai kinerja efisiensi yang digunakan untuk mengukur biaya output. Berdasarkan tabel 4, program yang dilakukan pemerintah Desa Garon beberapa cukup efisien dan beberapa tidak efisien. Pembangunan yang memiliki nilai di atas 100\% tidak efisien. Hal ini dikarenakan pemerintah Desa Garon belum mampu melaksanakan efisiensi biaya. Dimana menurut Mahmudi (2015: 85) suatu program dikatakan efisien apabila mampu menghasilkan output tertentu dengan input serendah-rendanhnya. Pembangunan saluran irigasi blok piket dan pembangunan talud memiliki nilai kinerja $100 \%$ berarti cukup efisien. Hal tersebut menunjukkan bahwa dalam pembangunan pemerintah Desa Garon telah melakukan efisiensi biaya.

Tabel 4. Nilai Kinerja Efisiensi Pemerintah Desa Garon Tahun 2016

\begin{tabular}{llrl}
\hline No & \multicolumn{1}{c}{ Program } & Nilai Efisiensi & \multicolumn{1}{c}{ Keterangan } \\
\hline 1. & Pembangunan pagar Balai Desa Garon & $101,38 \%$ & Tidak Efisien \\
\hline 2. & Pembangunan saluran irigasi blok gaprang & $101,65 \%$ & Tidak Efisien \\
\hline 3. & Pembangunan saluran irigasi blok piket & $100,42 \%$ & Cukup Efisien \\
\hline 4. & Penyemiran jalan RT 1, 2, 3, 4, 6 RW 02 & $106,80 \%$ & Tidak Efisien \\
\hline 5. & Penyemiran jalan RT 5 dan 7 RW 2 & $101,32 \%$ & Tidak Efisien \\
\hline 6. & Pembangunan Talud RT 05 & $100 \%$ & Cukup Efisien \\
\hline
\end{tabular}

Selanjutnya adalah menilai kinerja efektivitas Desa Garon. Berdasarkan tebel 5, keseluruhan pembangunan yang dilakukan pemerintah Desa Garon memiliki nilai kinerja efektivitas di atas $100 \%$. Hal tersebut berarti seluruh pembangunan yang dilakukan pemerintah Desa Garon memiliki kontribusi yang baik. Dimana realisasi lebih baik dari yang ditargetkan. Sehingga pembangunan yang dilakukan benar-benar memuaskan.

Tabel 5. Nilai Kinerja Efektivitas Pemerintah Desa Garon Tahun 2016

\begin{tabular}{clrl}
\hline No & \multicolumn{1}{c}{ Program } & Nilai Efektif & Keterangan \\
\hline 1. & Pembangunan pagar Balai Desa Garon & $100 \%$ & Efektif \\
\hline 2. & Pembangunan saluran irigasi blok gaprang & $102,66 \%$ & Efektif \\
\hline 3. & Pembangunan saluran irigasi blok piket & $101,66 \%$ & Efektif \\
\hline 4. & Penyemiran jalan RT 1, 2, 3, 4, 5 RW 02 & $100 \%$ & Efektif \\
\hline 5. & Penyemiran jalan RT 5, 6 dan 7 RW 2 & $100 \%$ & Efektif \\
\hline 6. & Pembangunan Talud RT 05 RW 01 & $100 \%$ & Efektif \\
\hline
\end{tabular}




\section{Pembahasan}

1. Akuntabilitas Hukum dan Kejujuran

Penyusunan Anggaran Pendapatan dan Belanja Desa Garon telah berlandaskan hukum antara lain Undang-undang Republik Indonesia No.06 Tahun 2014 Tentang Desa, Peraturan Pemerintah No.43 Tahun 2014 Tentang Peraturan Pelaksanaan Undang-undang No.06 Tahun 2014, Peraturan Pemerintah No.60 Tahun 2014 Tentang Dana yang bersumber dari Anggaran Pendapatan dan Belanja Desa, Peraturan Mentri dalam Negeri No.113 dan No.114 Tahun 2014 Tentang Pedoman Pengelolaan Keuangan Desa, Peraturan Menteri dalam Negeri No.85 Tahun 2015, Peraturan Daerah Kabupaten Magetan No.10 Tahun 2014 Tentang Anggaran Pendapatan dan Belanja Daerah Tanggal 17 Desember 2014.

2. Akuntabilitas Manajerial

Berdasarkan Permendagri No.114 Tahun 2014 perencanaan dan pelaksanaan pembangunan desa dilakukan melalui tahap Perencanaan pembangunan yang terdiri dari Rencana Pembangunan Jangka Menengah Desa untuk jangka waktu 6 tahun dan Rencana Kerja Pemerintah yang merupakan penjabaran dari Rencana Pembangunan Jangka Menengah Desa (RPJMDesa). Rencana Pembangunan Jangka Menengah Desa (RPJMDesa) dan Rencana Kerja Pemerintah Desa (RKPDesa) selanjutnya diterapkan dalam peraturan desa. Selanjutnya sekretaris desa menyusun rancangan Anggaran Pendapatan dan Belanja Desa dengan dasar Rencana Kerja Pembangunan Desa. Rancangan mengenai Anggaran Pendapatan dan Belanja Desa (APBDesa) diajukan kepada Kepala untuk dimusyawarahkan bersama Badan Permusyawaratan Desa, seluruh perangkat Desa dan tokoh masyarakat. Hasil musyawarah diajukan kepada bupati melalui camat. Beberapa hari setelah disetujui oleh bupati kepala desa akan mendapatkan informasi mengenai bantuan desa.

Pelaksanaan Anggaran Pendapatan dan Belanja Desa (APBDesa) dibahas dan disepakati dalam musyawarah desa yang diselenggarakan oleh Badan Permusyawaratan Desa. Pelaksana kegiatan bertugas membantu kepala desa dalam tahap persiapan dan tahap pelaksanaan kegiatan. Laporan kegiatan disusun berdasarkan pertanggungjawaban terhadap penggunaan dana yang diterima dari tahapan perkembangan pelaksanaan kegiatan.

Pertanggungjawaban kepada otoritas yang lebih tinggi berdasarkan Permendagri No.113 Tahun 2014 dilakukan dengan membuat laporan pertanggungjawaban yang dilampiri laporan pertanggungjawaban pelaksanaan APBDesa, laporan kekayaan milik desa dan laporan program pemerintah dan pemerintah daerah yang masuk desa. Untuk pertanggungjawaban kepada masyarakat dilakukan dengan memberikan informasi tentang Anggaran Pendapatan dan Belanja Desa di papan informasi desa.

Pemerintah Desa Garon telah memenuhi desain kelembagaan berdasarkan Peraturan Menteri dalam Negeri No.113 dan No.114 Tahun 2014 dan Undang-undang RI No.06 Tahun 2014. Namun pemerintah Desa Garon belum mempertanggungjawabkan Anggaran Pendapatan dan Belanja Desa (APBDesa) kepada masyarakat sehingga kurang sesuai dengan Peraturan Menteri No.113 Tahun 2014.

3. Akuntabilitas Program

Berdasarkan Peraturan Bupati Magetan Nomor 12 Tahun 2015, alokasi dana desa sebesar 30\% digunakan untuk biaya penyelenggaraan pemerintahan desa dan $70 \%$ digunakan untuk pemberdayaan masyarakat. Peraturan Pemerintah No.60 Tahun 2014 menjelaskan bahwa Dana Desa digunakan untuk penyelenggaraan pemerintahan, pemberdayaan masyarakat, pembangunan dan kemasyarakatan. 
Penggunaan Dana Desa Garon telah sesuai dengan Peraturan Bupati Magetan Nomor 12 Tahun 2015, dimana alokasi dana Desa Garon sebesar 30\% digunakan untuk biaya penyelenggaraan pemerintahan desa. Sedangkan 70\% alokasi dana Desa Garon digunakan untuk pemberdayaan masyarakat dibidang ekonomi, antara lain pelaksanaan pembangunan desa, pembinaan kemasyarakatan, dan pemberdayaan masyarakat. Program pembangunan yang dilakukan pemerintah Desa Garon telah sesuai dengan visi dan misi Desa Garon, yaitu mewujudkan sarana dan prasarana guna menunjang perekonomian masyarakat.

4. Akuntabilitas Kebijakan

Pengambilan kebijakan sesuai Permendagri No.114 dilakukan oleh kepala desa, dimana kepala desa membentuk tim untuk menyusun Rencana Pembangunan Jangka Menengah Desa (RPJMDesa). Rancangan Rencana Pembangunan Jangka Menengah Desa (RPJMDesa) memuat visi dan misi kepala desa, arah kebijakan pembangunan desa, serta rencana kegiatan yang meliputi bidang penyelenggaraan pemerintah desa, pelaksanaan pembangunan desa, pembinaan kemasyarakatan desa, dan pemberdayaan masyarakat desa. Tim penyusun Rencana Pembangunan Jangka Menengah Desa (RPJMDesa) melakukan penyelarasan arah kebijakan pembangunan kabupaten. Penyelarasan arah kebijakan dilakukan untuk mengintegrasikan program dan kegiatan pembangunan kabupaten dengan pembangunan desa.

Selanjutnya tim penyusun Rencana Pembangunan Jangka Menengah Desa (RPJMDesa) melakukan pengkajian keadaan desa. Pengkajian keadaan desa dilakukan dalam rangka mempertimbangkan kondisi objektif desa. Pengkajian keadaan desa meliputi penyelarasan data desa, penggalian gagasan masyarakat, penyusunan laporan hasil pengkajian keadaan desa. Laporan hasil pengkajian keadaan desa menjadi bahan masukan dalam musyawarah desa dalam rangka pnyusunan perencanaan pembangunan desa. Dalam mengambil kebijakan didukung dengan data desa mengenai daftar sumber daya alam dan sumber daya manusia, daftar gagasan dusun, berita acara hasil pengkajian desa, berita acara penyusunan Rencana Pembangunan Jangka Menengah Desa (RPJMDesa) dan Rnecana Kerja Pembangunan Desa (RKPDesa).

Kebijkan yang di ambil oleh pemerintah Desa Garon telah selaras dengan visi misi Desa Garon, keadaan desa, arah kebijakan pemerintah Kabupaten Magetan sebagaimana yang diamanatkan dalam Peraturan Menteri dalam Negeri N0.114 Tahun 2014.

5. Akuntabilitas Finansial

Secara keseluruhan nilai ekonomi dari pembangunan yang dilakukan telah sesaui dengan yang ditargetkan. Pembangunan yang dilakukan pemerintah Desa Garon beberapa cukup efisien dan beberapa tidak efisien. Hal ini dikarenakan pemerintah Desa Garon belum mampu melaksanakan efisiensi biaya. Pembangunan yang dilakukan pemerintah Desa Garon memiliki kontribusi yang baik. Dimana realisasi lebih baik dari yang ditargetkan. Sehingga pembangunan yang dilakukan benar-benar memuaskan.

\section{SIMPULAN}

Kesimpulan hasil penelitian ini adalah pertama, akuntabilitas hukum dan kejujuran, Desa Garon telah menjadikan Undang-undang sebagai dasar penyusunan APBDesa, antara lain Undang-undang RI No.06 Tahun 2014, Peraturan Menteri dalam Negeri No.83, 113 dan 114, Peraturan Pemerintah No.60 Tahun 2014, Peraturan Bupati Magetan No.12 Tahun 2015. Kedua, akuntabilitas manajerial, pemerintah Desa Garon telah memenuhi desain kelembagaan berdasarkan Peraturan Menteri dalam Negeri 
No.114 Tahun 2014 serta Undang-undang RI No.06 Tahun 2014. Namun pemerintah Desa Garon belum mempertanggungjawabkan APBDesa kepada masyarakat sehingga kurang sesuai dengan Peraturan Menteri No.113 Tahun 2014. Ketiga, akuntabilitas program, Dana Desa Garon telah sesuai dengan Peraturan Bupati Magetan Nomor 12 Tahun 2015, dimana alokasi dana Desa Garon sebesar 30\% digunakan untuk biaya penyelenggaraan pemerintahan desa. Sedangkan 70\% alokasi dana Desa Garon digunakan untuk pemberdayaan masyarakat dibidang ekonomi. Program pembangunan yang dilakukan pemerintah Desa Garon telah sesuai dengan visi dan misi Desa Garon, yaitu mewujudkan sarana dan prasarana guna menunjang perekonomian masyarakat. Keempat, akuntabilitas kebijakan, kebijkan yang di ambil oleh pemerintah Desa Garon telah selaras dengan visi misi Desa Garon, keadaan desa, dan arah kebijakan pemerintah Kabupaten Magetan sebagaimana yang diamanatkan dalam Peraturan Menteri dalam Negeri N0.114 Tahun 2014. Kelima, akuntabilitas finansial, pertanggungjawaban pemerintah Desa Garon terhadap Anggaran Pendapatan dan Belanja Desa yang digunakan untuk pembangunan cukup ekonomis yaitu target yang ditetapkan sesuai dengan realisasi. Pembangunan tidak efisien dikarenakan pemerintah Desa Garon kurang mampu melakukan efisiensi biaya saat melaksanakan pembangunan. Program pembangunan sarana dan prasarana yang telah dilakukan cukup efektif. Hal ini dikarenakan program tersebut memberikan kontribusi yang baik bagi masyarakat. Realisasi program jauh lebih baik dari yang ditetapkan dan memberikan dampak langsung bagi perekonomian masyarakat Desa Garon.

Penelitian selanjutnya diharapkan dapat menggunakan lebih dari satu periode laporan pertanggungjawaban, untuk mengetahui konsistensi akuntabilitas Anggaran Pendapatan dan Belanja Desa. Penelitian selanjutnya hendaknya memaparkan semua data terkait sumber daya alam, sumber daya manusia dan sketsa desa yang merupakan bagian dari data untuk menyusun perencanaan dan pembangunan desa.

\section{DAFTAR PUSTAKA}

Arifiyanto, D. F. \& Kurohman, T. (2014). Akuntabilitas Pengelolaan Alokasi Dana Desa di Kabupaten Jember. Jurnal Riset Akuntansi dan Keuangan. 2 (03) : 473-485.

Faridah \& Suryono, B. (2015). Transparansi dan Akuntabilitas Pemerintah Desa dalam Pengelolaan Anggaran Pendapatan dan Belanja Desa. Jurnal Ilmu dan Riset Akuntansi. 4 (05) : 1-20.

Hanifah, S. I. \& Praptoyo, S. (2015). Akuntabilitas dan Transparansi Pertanggungjawaban Anggaran Pendapatan Belanja Desa (APBDes). Jurnal dan Riset Ilmu Akuntansi, 4 (08): 1=15.

Hariyani, D. S. \& Sudrajat, M. A. (2016). Analisis Pengaruh Kopetensi Aparatur Pemerintah Desa terhadap Penggunaan Teknologi Accounting Information System pada Desa-desa di Kabupaten Madiun. Assets: Jurnal Akuntansi dan pendidikan. 5 (02) : 113-128.

Kurniawan, H., Made, A. \& Yogivaria, D. W.. (2014). Akuntabilitas Pengelolaan Alokasi Dana Desa. Journal Riset Mahasiswa. 20 (20): 1-15.

Lestari, A. K. D., Atmadja, A. T., \& Adiputra, I M. P. (2014). Membedah Praktik Desa Pakraman Kubutambahan Kecamatan Kubutambahan Kabupaten Buleleng Provinsi Bali. E-journal s1 akuntansi Universitas Pendidikan Ganesha, 2(1). : 1-12.

Mahmudi. (2015). Manajemen Kinerja Sektor Publik. Edisi Ketiga. Yogyakarta: Sekolah Tinggi Ilmu Manajemen YKPN.

Nurcholis, H. (2011). Pertumbuhan dan Penyelenggaraan Pemerintah Desa. Jakarta: Erlangga. 
Peraturan Menteri dalam Negeri Nomor 113 Tahun 2014 Tentang Pengelolaan Keuangan Desa. (2015). Bandung: Fokusmedia.

Riyanto, T. (2015). Akuntabilitas Finansial dalam Pengelolaan Alokasi Dana Desa di Kantor Desa Perangkat Selatan Kecamatan Marangkayu Kabupaten Kutai Kartanegara. E-journal administrasi Negara, 3(1). : 199-130.

Sa'adah, B. (2015). Akuntabilitas dan Transparansi Anggaran melalui E-Government. Jurnal Kebijakan dan Manajemen Publik. 3 (02) : 1-10.

Sugiyono. (2016). Metode Penelitian Kuantitatif, Kualitatif dan RED. Bandung: Alfabeta.

Undang-undang Nomor 06 Tahun 2014 Tentang Desa. Pemerintah Negara Republik Indonesia. 2014. Jakarta.

Suharto, D. G. (2016). Membangun Kemandirian Desa. Yogyakarta: Pustaka Pelajar.

Mardiasmo. (2009). Akuntansi Sektor Publik. Yogyakarta: Penerbit Andi.

Setiawan, A., Haboddin, M., \& Wilujeng, N. F. (2017). Akuntabilitas Pengelolaan Dana Desa di Desa Budugsidorejo Kabupaten Jombang Tahun 2015. Jurnal Politik Indonesia, 2(1) : 1-16. 


\section{Lampiran Pedoman Wawancara kepada Kepala Desa Garon:}

1. Sejak kapan pemerintah Desa Garon menerapkkan UU RI No.06 tahun 2014?

2. Apa saja peraturan yang digunakan dalam menyusun Anggaran Pendapatan dan Belanja Desa Garon?

3. Bagaimana proses penyusunan Anggaran Pendapatan dan Belanja Desa Garon?

4. Untuk pelaksanaan APBDesa Garon seperti apa?

5. Pemasukan dan pengeluaran APBDesa Garon apa harus dilakukan melalui rekening desa?

6. Bagaimana pertanggung jawaban pemerintah Desa Garon kepada otoritas yang lebih tinggi?

7. Bagaimana pertanggungjawaban pemerintah Desa Garon kepada masyarakat mengenai APBDesa?

8. Dalam melaksanakan kegiatan kepala desa dibantu oleh siapa?

9. Tim pelaksana program itu siapa?

10. Proses penyusun APBDesa Garon itu seperti apa?

11. Pelaksanaan pembangunan desa setelah dana turun itu sepertia apa?

12. Pembangunan yang dilakukan apakah sesuai dengan visi dan misi Desa Garon?

\section{Lampiran Pedoman Wawancara kepada Sekretaris Desa Garon:}

1. Apa dasar penyusunan APBDesa Garon?

2. Bagaimana proses penyusunan APBDesa Garon?

3. Untuk perencanaan APBDesa Garon itu seperti apa?

4. Pelaksanaannya seperti apa?

5. Untuk program pemerintah yang masuk desa itu ada atau tidak pak dan laporannya seperti?

6. Pertanggungjawaban yang dilakukan kepada masyarakat seperti apa?

7. Desa Garon kan melakukan beberapa pembangunan, nah itu berapa panjang dan tinggi pagar balai Desa Garon yang telah dilakukan pembangunan?

8. Apakah ada pencurian di Kantor Desa Garon setelah dilakukan pembangunan?

9. Untuk pembangunannya ada sarana prasarana yang digunakan apa tidak?

10. Berapa panjang dan lebar saluran irigasi blok gaprang dan blok piket?

11. Seberapa lancar saluran irigasi setelah dilakukan pembangunan?

12. Setelah dilakukan pembangunan adakah komplain dari masyarakat saat menggunakan saluran irigasi?

13. Sarana dan prasarana yang digunakan apa saja?

14. Berapa panjang dan lebar jalan yang dilakukan penyemiran?

15. Adakah komplain dari masyarakat setelah dilakukan penyemiran jalan?

16. Sarana dan prasarana yang digunakan apa saja?

17. Selama tahun 2016 berapa jumlah kecelakaan dijalan yang telah dilakukan penyemiran?

18. Ada satu lagi pembangunan yang dilakukan pemerintah desa pada tahun 2016 yaitu talud, nah itu pajangnya berapa?

19. Sarana dan prasaranayang digunakan apa saja?

20. Setelah dilakukan pembangunan talud ada komplain dari warga atau tidak?

21. Dana Desa Garon pada tahun 2016 lebih diutamakan untuk apa?

22. Dalam melaksanakan pembangunan kepala desa dibantu siapa?

23. Setiap pembangunan yang dilakukan apakah tim pelaksana selalu sama?

24. Seperti apa tata kelola Desa Garon?

25. Selama tahun 2016 apakah pemerintah Desa Garon memperoleh sosialisasi terkait arah kebijakan yang akan diambil? 


\section{ASSEIS JURNAL AKUNTANSI DAN PENDIDIKAN}

26. Dalam menyusun APBDesa sekretaris dibantu oleh siapa?

27. Susunan organisasi Desa Garon seperti apa?

28. Proses penyusun APBDesa Garon itu seperti apa?

29. Pelaksanaan pembangunan desa setelah dana turun itu sepertia apa?

30. Pembangunan yang dilakukan apakah sesuai dengan visi dan misi Desa Garon?

31. Sebelum melakukan pembangunan apakah ada keluhan-keluhan dari masyarakat?

\section{Lampiran Pedoman Wawancara kepada Bendahara Desa Garon:}

1. Peraturan yang digunakan untuk menyusun APBDesa itu apa saja ya?

2. Bagaimana perencanaan APBDesa Garon?

3. Untuk pelaksanaan APBDesa Garon itu seperti apa?

4. Untuk rekening desa itu kalo boleh tahu rekening bank apa yang digunakan?

5. Bagaimana pengelolaan Sisa Lebih Pembiayaan Anggaran suatu program yang telah dilaksanakan?

6. Apa yang menyebabkan rencana anggaran dan realisasi anggaran berbeda?

7. Dalam pelaksanaan pembangunan bendahara memberikan wewenang kepada siapa untuk membelanjakan bahan material dan jasa?

8. Proses penyusun APBDesa Garon itu seperti apa?

9. Pelaksanaan pembangunan desa setelah dana turun itu sepertia apa?

10. Pembangunan yang dilakukan apakah sesuai dengan visi dan misi Desa Garon?

\section{Lampiran Pedoman Wawancara kepada Ketua RT (sebagai perwakilan masyarakat)} Desa Garon:

1. Dalam merencanakan APBDesa Garon bapak sebagai ketua RT dan perwakilan masyarakat apakah diikutsertakan?

2. Setelah adanya pembangunan infrastruktur terutama dibidang pertanian salah satunya saluran irigasai, menurut bapak sebagai petani dampak yang dirasakan seperti apa?

3. Selain pembangunan dalam bidang pertanian pemerintah Desa Garon juga melakukan penyemiran jalan, bapak sebagai masyarakat Desa Garon apa yang dirasakan setelah dilakukan penyemiran jalan?

\section{Lampiran Pedoman Wawancara kepada Anggota Badan Permusyawaratan Desa} Garon:

1. Badan Permusyawaratan Desa itu sebenarnya apa?

2. Kalau boleh tahu anggota BPD Desa Garon ada berapa?

3. Peran BPD dalam penyusunan APBDesa itu seperti apa?

4. Dalam pelaksanaan suatu program apa BPD ikut berperan?

5. Untuk pertanggungjawaban APBDesa Garon seperti apa?

6. Apa BPD juga sebagai penampung aspirasi masyarakat?

7. Pada dasarnya apa BPD itu sebagai penampung aspirasi masyarakat, pengawas kepala desa dan pihak yang menyetujui peraturan desa? 